\title{
What happens after technology adoption? Gendered aspects of small- scale irrigation technologies in Ethiopia, Ghana, and Tanzania
}

\author{
Sophie Theis $^{1}$ [D $\cdot$ Nicole Lefore $^{2} \cdot$ Ruth Meinzen-Dick ${ }^{1} \cdot$ Elizabeth Bryan $^{1}$
}

Accepted: 6 April 2018 / Published online: 25 April 2018

(c) The Author(s) 2018

\begin{abstract}
Diverse agricultural technologies are promoted to increase yields and incomes, save time, improve food and nutritional security, and even empower women. Yet a gender gap in technology adoption remains for many agricultural technologies, even for those that are promoted for women. This paper complements the literature on gender and technology adoption, which largely focuses on reasons for low rates of female technology adoption, by shifting attention to what happens within a household after it adopts a technology. Understanding the expected benefits and costs of adoption, from the perspective of women users in households with adult males, can help explain observed technology adoption rates and why technology adoption is often not sustained in the longer term. Drawing on qualitative data from Ethiopia, Ghana, and Tanzania, this paper develops a framework for examining the intrahousehold distribution of benefits from technology adoption, focusing on small-scale irrigation technologies. The framework contributes to the conceptual and empirical exploration of joint control over technology by men and women in the same household. Efforts to promote technology adoption for agricultural development and women's empowerment would benefit from an understanding of intrahousehold control over technology to avoid interpreting technology adoption as an end in and of itself.
\end{abstract}

Keywords Irrigation $\cdot$ Agricultural technology $\cdot$ Technology adoption $\cdot$ Gender $\cdot$ Small-scale irrigation

\section{Introduction}

In light of evidence that women's limited access to agricultural technology is an important constraint to women's agricultural productivity (von Braun and Webb 1989; Quisumbing 1995; Peterman et al. 2010), increasing technology adoption among women farmers has emerged as a key strategy to close the gendered productivity gap in agriculture

Sophie Theis

s.theis@cgiar.org

Nicole Lefore

n.lefore@cgiar.org

Ruth Meinzen-Dick

r.meinzen-dick@cgiar.org

Elizabeth Bryan

e.bryan@cgiar.org

1 Environment and Production Technology Division, International Food Policy Research Institute, 1201 Eye Street NW, Washington, DC 20005, USA

2 International Water Management Institute, Private Bag X813, Silverton, Pretoria 0127, South Africa while also promoting women's empowerment and advancing broader welfare outcomes. Agricultural technologies can help women farmers-particularly small-scale, resourcepoor women farmers-produce more; add value; manage risk; and use less energy, time, and natural resources. These production and quality improvements can enable women to maximize the returns to their limited time, labor, land, and capital (Doss 2001).

Given these expected benefits, research has sought to understand what keeps women's observed rates of agricultural technology adoption low. The literature has shown that men and women have different preferences and face different types and severity of constraints to adopting technology (Doss 2001; Doss and Morris 2001; Carr and Hartl 2010; Quisumbing and Pandolfelli 2010; Ragasa et al. 2014).

Technology adoption can be understood as three phases: awareness, tryout, and continued adoption (Lambrecht et al. 2014; Lindner et al. 1982). Each phase presents certain challenges for women farmers. Awareness is limited by factors such as women's mobility and access to information and extension services that would help them learn what technologies are available, how to acquire them, and how to 
use them (Doss et al. 2003; Ragasa et al. 2014). Tryout is limited by access to and control over the land, water, labor, inputs, and other assets required to use the technology (Ani et al. 2004; Drechsel et al. 2006; Meinzen-Dick et al. 2011; Ragasa et al. 2014; Johnson et al. 2016); access to capital or credit to invest in the technology (Tiwari 2010; Ragasa et al. 2014; Doss et al. 2003; Olwande et al. 2009); access to social networks, learning, and social capital to reduce perceived risks associated with technology adoption (Conley and Udry 2001; Magnan et al. 2014; Hunecke et al. 2017); and appropriateness of design, including affordability, cultural acceptability, and suitability for women's specific agricultural tasks and physical requirements (Quisumbing and Pandolfelli 2010). Thus, many of the constraints that technology promises to alleviate are the same constraints that hamper adoption in the first place.

Notably, this literature has implicitly focused on the first two phases of technology adoption and devoted less attention to continued adoption. As Peterman et al. (2011) note, use, access, and adoption are often used interchangeably in the literature. This emphasis reflects an optimistic assumption that removing constraints to access or use technology could be sufficient for women to empower themselves. However, even if the removal of such gender-based constraints may be able to increase rates of women's acquisition of technology, women's particular experience with that technology cannot be assumed. In households with multiple decision-makers, how the technology is used, and to whose benefit, must be negotiated between people with both overlapping and separate interests.

As Lambrecht et al. (2014) points out, during the continued adoption phase, farmers assess based on their own experience whether the returns from the technology relative to labor and input requirements are worth its continued use. These returns and costs likely will not be the same for all household members. Several studies document important changes in gender roles after a technology has been acquired, including shifting burdens of labor and control over agricultural outputs (e.g., von Braun and Webb 1989; Doss 2001; Njuki et al. 2014). However, few studies have examined who bears the costs or controls the benefits of a new technology.

This paper contributes to the gender and technology adoption literature by shifting attention to what happens after technology adoption or acquisition, during the phase of continued use. We examine evidence on the intrahousehold negotiations and roles in technology adoption gathered through qualitative fieldwork on dual-headed households using small-scale irrigation technologies in Ethiopia, Ghana, and Tanzania.

Small-scale irrigation technologies, particularly waterlifting technologies (e.g., rope and washer, motor, treadle, and solar pumps), are intended for smallholders to use on their farm plots and homestead gardens, exclusively or in conjunction with water-application technologies such as drip systems, buckets, cans, or hoses. Despite the extensive use of small-scale irrigation, official statistics frequently underreport the value and extent of its use (Woodhouse et al. 2017; de Fraiture and Giordano 2014). The area in Africa south of the Sahara irrigated with groundwater is estimated at 340,134 hectares (Siebert et al. 2010), but a separate study has suggested that the area is likely much larger, as smallholder farmers also widely use small pumps to lift surface water (Merrey 2006). In many countries in the region, smallholder irrigation area is estimated to be as large as or larger than that of large-scale irrigation schemes (Namara et al. 2014; Beekman et al. 2014), and the potential for further smallholder expansion surpasses that of largescale development potential (You et al. 2010; Xie et al. 2014). The Comprehensive Africa Agriculture Development Programme under the New Partnership for Africa's Development is targeting 14.2 million hectares for small-scale irrigation development, about 7.5 times the area proposed for large-scale irrigation development (NEPAD/CAADP 2009). Small-scale irrigation technologies are increasingly being promoted in an effort to improve smallholders' dietary diversity, health, seasonal food security, and resilience to climate change and weather shocks (Domènech 2015).

Nonetheless, numerous studies have found that women are less likely than men to access both large- and small-scale irrigation infrastructure and technologies. In large-scale farmer-led irrigation schemes, women's implicit and explicit exclusion from scheme management decisions and irrigated land allocation limit their access to water (Zwarteveen 1997; Meinzen-Dick and Zwarteveen 1998; van Koppen 1998). Moreover, relatively less attention has been paid to the gender aspects of small-scale irrigation technologies. Many studies that have investigated the gender gap in adoption and the different kinds of technology men and women prefer (e.g., Upadhyay 2004) mainly compare male- and femaleheaded households, rather than looking at intrahousehold dynamics in dual-headed (also called male-headed) households. A cross-country study in Ghana and Zambia found that female-headed households adopt small-scale technologies at two-thirds the rate of male-headed households; and that whereas female-headed households are more likely to adopt manual technologies (e.g., buckets, wetlands), maleheaded households are more likely to adopt motor pumps and river diversions (van Koppen et al. 2012). Analyzing 2005-2013 sales data from KickStart, a nongovernmental organization (NGO), Njuki et al. (2014) find that women made up only 6 percent in Tanzania and 18 percent in Kenya of all buyers of motor pumps. These buyers were rarely women in married households purchasing pumps for their own use, but rather were unmarried women or married women purchasing pumps on behalf of their husbands. 
These studies have shown that female-headed households face unique constraints to adopting technology. However, this focus also assumes that women in so-called male-headed households can rely on their husband to access technology. However, a comparison between male- and female-headed households excludes the majority of women, who live in socalled male-headed households. Households with more than one adult decision-maker, with both jointly and separately managed plots of land, and some shared and some independent assets and sources of income-common in our study communities and much of Africa South of the Sahara-create conditions for technology to affect different household members in different ways. To evaluate these differences, our inquiry focuses on dual adult households.

Several studies examine the dynamics related to how men and women in the same household control and benefit from irrigation, such as deciding what to grow on irrigated land, providing labor on irrigated plots, deciding whether to sell or consume irrigated produce, and controlling income from irrigated plots. Njuki et al. (2014) report that men prefer to irrigate cash crops like tomatoes and women prefer to irrigate leafy vegetables that can be sold in smaller quantities over a longer period to retain control over these earnings. They also note that though women in pump-owning households have less say over production decisions overall, they are able to use the pump for the plots they manage themselves. This is one of the few studies, however, to explore how technology adoption affects the whole household-not just the adopter or owner-in different ways.

Rather than taking technology adoption as a goal in and of itself, understanding the differentiated impacts of technology within the household can help orient technology promotion activities to more strategically advance specific development objectives. In this paper, we propose an analytical framework for analyzing intrahousehold dynamics-specifically considered as rights to small-scale irrigation technology. We then apply the framework to case studies using qualitative evidence of small-scale irrigation from Ghana, Ethiopia, and Tanzania.

Two bodies of literature inform our analysis. First, the literature on gender and assets highlights complexity in defining "joint" ownership of resources (Johnson et al. 2016; Huyer 2016). Second, the property rights literature (e.g., Alchian and Demsetz 1972; Eggertsson 1990; Schlager and Ostrom 1992) provides concepts that help us identify overlapping bundles of rights over assets, including technologies. By focusing on property rights as social relations among people with respect to assets, rather than as relations between people and things (Benda-Beckmann et al. 2006), this literature sheds light on the institutions that set and enforce rules over who can use which resources in what ways. We have found that bringing together these two bodies of literature, extending the analysis of property rights as social relations to analyses within the household, provides useful new insights.

The paper is organized as follows. It begins by presenting the analytical concepts and framework, then describes the methodology. "Results" section presents the evidence to illustrate these concepts, examining the intrahousehold distribution of rights during continued adoption. "Discussion and conclusion" section concludes with implications for technology adoption research and programs in general and insights for sustained adoption of small-scale irrigation technology in particular.

\section{Analytical concepts and framework}

Although it is well established that members of households do not share all the same preferences or pool all resources to improve overall welfare (Alderman et al. 1995; Doss 1996; Doss et al. 2014), in rural settings household members do share some degree of joint use and decision making over assets. Meinzen-Dick et al. (2011) describe this idea in terms of a spectrum of jointness and separateness with regard to assets within the household.

"Ownership" and "control" can describe a range of possible social relations with respect to an asset. Identifying specific rights that comprise ownership and control can help assess the implications of different rights, including the benefits and costs conferred to different people within the household.

The social science literature on property rights can help to elucidate these issues. Rights may seem too strong a word for many of the arrangements governing intrahousehold use and control of technologies, but the literature conceives of property rights as social relations, backed by particular institutions. Yet even though the property rights literature has focused on state, community, and religious institutions, it has not looked deeply into households as institutions that shape property rights. In much the same way that communities use collective resources, households can also be viewed as an institution that recognizes and enforces property rights (Doss and Meinzen-Dick 2015). These are de facto rights, determined by the social norms influenced by historical, institutional, and legal contexts, and usually enforced by other household members.

In particular, the concept of bundles of rights allows us to identify how different actors can claim different types of rights over a resource or asset. Although it is possible to identify many different individual rights, there are two major ways of classifying bundles of rights.

Schlager and Ostrom (1992, pp. 250-251) refer to a hierarchy of five bundles of rights, which they apply to natural resources: 
Table 1 Bundle of rights concepts and definitions Source: Authors, drawing from Schlager and Ostrom (1992) and Benjaminsen and $\mathrm{Ba}(2009)$

\begin{tabular}{ll}
\hline Right & Definition \\
\hline Use & The right to use and physically operate the technology \\
Management & The right to make decisions how, when, and where to apply the technology \\
Fructus & The right to control outputs and profits generated by the use of technology \\
Alienation & The right to sell, lease, or give away the technology \\
\hline
\end{tabular}

- Access The right to enter the physical space of the resource (e.g., walk through the forest)

- Withdrawal The right to take the products of a resource (e.g., catch fish, remove water)

- Management The right to regulate use and modify or transform the resource

- Exclusion The right to determine who can use the resource

- Alienation The right to lease, sell, or transfer either the management or exclusion rights associated with the resource, or both.

The first two of these are generally considered use rights, while the latter three are control or decision-making rights. Ownership is generally considered to be having all of these rights, including alienation. These classifications have proved useful for analyzing land and natural resource management.

In synthesizing the results of eight agricultural development projects on women's empowerment, Johnson et al. (2016) focus on three key bundles: use, control (which includes decision-making rights of management and exclusion), and ownership, which includes all bundles of rights. Useful as this classification is, however, it misses one aspect of fundamental importance for intrahousehold control over agricultural technologies: the control of the income (or other benefits) generated by the technology.

Several studies have indicated that control over income can diverge from self-reported ownership. Quisumbing et al. (2013) found that a dairy value-chain intervention increased the value of jointly owned assets but that men controlled all decisions related to financial transactions, including revenues from milk sales, whether to sell milk, and whether to buy or sell cows. In their research on flypaper effects, examining whether targeted asset transfers for ultra-poor women "stick" to women in Bangladesh, Roy et al. (2015) found that, at least in the short term, women were able to retain control over an asset transferred to them, but men predominantly controlled the revenue generated by the asset for investments of their choosing.

An alternative way of identifying bundles of rights derives from ancient Roman law and is reflected in most civil law systems today, capturing this control over income in the fructus concept (see Benjaminsen and Ba 2009, p. 77):
- Usus The right to use

- Fructus The right to the products, increase, or profits of the resource

- Abusus The right to encumber or dispose of property through donation, sale, destruction.

This Roman legal terminology partially overlaps with Schlager and Ostrom's (1992) framework. The term "usus" covers the use rights of access and withdrawal from the Schlager and Ostrom framework, and "abusus" corresponds with Schlager and Ostrom's alienation rights. However, the Roman classification does not include the management and exclusion rights found in the Schlager and Ostrom framework, and the "fructus" rights from Roman law are not included in the Schlager and Ostrom classification. Therefore, bringing together these two frameworks yields the following bundle of rights, which can be used to describe intrahousehold dynamics: use, management, fructus, ${ }^{1}$ and alienation (Table 1). In the case of irrigation technology, use and management refer to rights over the application of the technology, whereas fructus and alienation refer to the rights to the benefits of the technology.

Just as various institutions at different scales influence the rules of resource use, different institutions affect intrahousehold resource allocation and control over technologies. A right that is recognized across multiple institutions tends to increase the strength of the right; conversely, it is more challenging to claim rights to an asset that is not backed up by institutions beyond the household level. Analyzing technologies in this way can show how the benefits and costs of a technology are distributed across different members of the household, which influences their preferences for and willingness to try out and continue use of technologies, as illustrated in Fig. 1.

\footnotetext{
1 Although the original Roman law terms "usus" and "abusus" adequately translate in our framework to "use" and "alienation" rights, we have chosen to preserve the term "fructus" here in the absence of a precise and appropriate English nomenclature that captures the meaning of the right to have profit or loss of income or products.
} 


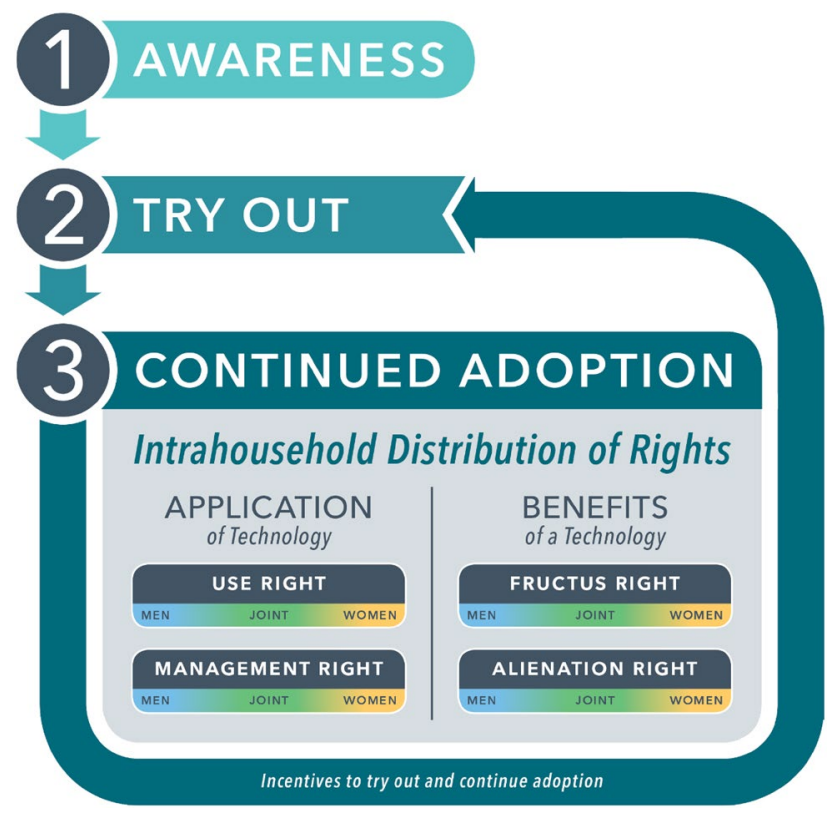

Fig. 1 Gender in the three phases of technology adoption

\section{Methods and procedures}

This study draws on qualitative data collected in 19 communities in Ethiopia, Ghana, and Tanzania in 2016. In total, we conducted 38 gender-separated focus group discussions with 375 men and women. The fieldwork took place in smallscale irrigation pilot sites of the Feed the Future Innovation Lab for Small Scale Irrigation (ILSSI) ${ }^{2}$ in Ethiopia, Ghana, and Tanzania and the Helen Keller International (HKI) Enhanced Homestead Food Production project in Tanzania (Helen Keller International 2014).

The sites for the ILSSI pilot studies were chosen based on access to an adequate source of water for dry-season irrigation, proximity to an output (produce) market, some experience with manual irrigation (bucket-based), and community interest in participating in a pilot using their own land, labor, and other inputs. ILSSI then worked with these communities, local government and customary authorities, and extension agents to choose an irrigation technology to pilot in the area. The initial list of technologies proposed to the community was based on national stakeholder consultation and priorities aligned with government policy, then further refined based on the biophysical suitability of the community. Technologies included petrol-fueled motorized pumps, photovoltaic solar pumps, and manual water-lifting technologies (e.g., rope and washer or pulley) in combination with various field-application technologies (e.g., drip,

\footnotetext{
2 "Innovation Lab for Small Scale Irrigation," Feed the Future Innovation Lab, n.d., http://ilssi.tamu.edu/.
}

furrow) and irrigation-scheduling tools (Table 2). Communities decided themselves who would participate in the pilots based on access to land and willingness to invest time and in-kind resources without guaranteed returns in irrigating with the technology. The project distributed solar-pump and manual-lifting technologies to individual farmers, and gave motor pumps went to a few small groups of farmers. About 200 farmers in total piloted the technologies, and committed to paying for the technologies over the period of the field intervention. Households decided themselves who within the household would use and control the technology. Our research focused on understanding these decisions.

The HKI project follows a model of Village Model Farms and Farmer Field Schools that target women for training on homestead food production and nutrition. In the Ukerewe and Sengerema districts in the Mwanza region of Tanzania, IFPRI linked a local NGO, Sustainable Environment Management Action (SEMA), with HKI, through HKI's project Creating Homestead Agriculture for Nutrition and Gender Equity (CHANGE). The CHANGE project aimed to improve the nutritional status of infants and young children and their mothers through interventions targeted to women to enhance homestead food production and induce nutrition behavior change. Through the collaboration with SEMA, drip kits were integrated into the CHANGE project. Specifically, SEMA distributed 78 drip kits to CHANGE beneficiary farmers (all women) and provided technical assistance on drip kit installation, use, and maintenance to resource farmers and other community members. The fieldwork included control sites in the same district, with comparable agroecological conditions and livelihoods, but where no small-scale irrigation activities were being promoted.

We applied a focus group protocol consistently across all sites involving separate group discussions with women and men farmers. Participants were recruited in consultation with key informants in the villages studied, following selection criteria that included a combination of irrigators and nonirrigators or rainfed producers, women and men, field intervention participants and nonparticipants, and age groups. We focused on married women and men in dualheaded households to explore intrahousehold dimensions of technology use.

The discussion questions for focus groups examined gender preferences for water technologies, technology choices as aligned to existing community and household needs, roles and responsibilities of both men and women, household use and management of water with different technologies, and perceived benefits and incentives related to small-scale irrigation technology adoption. Between 5 and 16 men or women participated in each focus group (Table 2). Discussions took place in Swahili in Tanzania, Amharic in Ethiopia, and Gurunsi and Dagbani in Ghana. The discussions lasted about two hours and were held in primary schools or 
Table 2 Locations, pilot technologies, and number of participants in focus group discussions

\begin{tabular}{|c|c|c|c|c|c|}
\hline Site & Region & Men & Women & Project & Pilot technology \\
\hline \multicolumn{6}{|l|}{ Ghana } \\
\hline Zanlerigu & Upper East & 6 & 9 & ILSSI & Rainwater harvesting; drip \\
\hline Nyangua & Upper East & 12 & 5 & Control & - \\
\hline Dimbisinia & Upper East & 11 & 6 & ILSSI & Motor pump \\
\hline Bihinayiili & Northern & 16 & 15 & ILSSI & Motor pump \\
\hline \multicolumn{6}{|l|}{ Ethiopia } \\
\hline Robit Bata & Amhara & 13 & 13 & ILSSI & Pulley \\
\hline Dangila & Amhara & 11 & 9 & ILSSI & Pulley \\
\hline Upper Gana, Jawe (Lemo) & $\begin{array}{l}\text { Southern Nations, Nationali- } \\
\text { ties, and Peoples' (SNNP) }\end{array}$ & 9 & 12 & ILSSI & Solar pump; rope and washer \\
\hline \multicolumn{6}{|l|}{ Tanzania } \\
\hline Rudewa Mbuyuni, Kilosa District & Morogoro & 10 & 9 & ILSSI & Motor pump \\
\hline Sangasanga, Kilosa District & Morogoro & 9 & 11 & Control & - \\
\hline Mkindo, Mvomero District & Morogoro & 9 & 9 & ILSSI & Motor pump \\
\hline Kondoa, Mvomero District & Morogoro & 10 & 10 & Control & - \\
\hline Mawemairo, Babati District & Manyara & 8 & 10 & ILSSI & Motor pump \\
\hline Mapea, Babati District & Manyara & 9 & 9 & Control & - \\
\hline Nyampande, Sengerema District & Mwanza & 8 & 10 & HKI & Drip kit \\
\hline Nyamazugo, Sengerema District & Mwanza & 8 & 10 & HKI & Drip kit \\
\hline Chifumfu, Sengerema District & Mwanza & 9 & 12 & HKI & Drip kit \\
\hline Nyamatongo, Sengerema District & Mwanza & 9 & 11 & HKI & Drip kit \\
\hline Muriti, Ukerewe District & Mwanza & 9 & 11 & HKI & Drip kit \\
\hline Kazilankanda, Ukerewe District & Mwanza & 9 & 9 & HKI & Drip kit \\
\hline
\end{tabular}

neutral community settings with visual and audio privacy. The authors trained a team of national facilitators in each country to conduct focus group discussions using this protocol. Male facilitators led the male discussions and female facilitators led the female discussions, with notetakers assisting them and recording the meetings. Afterward, recordings were transcribed and translated into English. Responses and comments from each focus group were then organized into spreadsheets following the modules to enable cross-group and cross-country comparison.

\section{Results}

Interviews with men and women from 19 communities in Ethiopia, Ghana, and Tanzania reveal several broad patterns in intrahousehold rights over irrigation technologies after the technology is first adopted.

The data from the three countries show that the costs and benefits of technology adoption are not equally distributed across the household. One member of the household generally does not exclusively hold rights of use, management, fructus, and alienation, but men are more likely to hold more of these rights as well as stronger claims to these rights. Use and management rights do not guarantee fructus or alienation rights. In this section, we discuss findings on gendered constraints in the first two phases of technology adoption, awareness and tryout, then examine intrahousehold use, management, fructus, and alienation rights over small-scale irrigation technology.

\section{Use rights}

Of all the rights identified, use rights are most likely to be held jointly. However, even though use is generally recognized as a right in the property-rights literature and encouraged through the promotion of "women-friendly technologies" (Ethiopian Agricultural Transformation Agency 2018) it also is an obligation with time and energy costs. Consistent with findings from earlier work (van Koppen et al. 2012; Njuki et al. 2014), women often have the right to use manual, labor-intensive irrigation technologies such as buckets and watering cans, while men operate mechanized irrigation technologies such as motorized pumps.

Although there was no outright opposition expressed to women's use of pumps, men provide various rationalizations for why women do not typically use pumps, including the pump's technological complexity, physical requirements to operate, and women's difficulty hiring and supervising laborers. In part because of the labor requirements and costs of 
fuel, the use of pumps is considered worthwhile for higher market value crops ${ }^{3}$ but not for subsistence agriculture. Because women tend to cultivate separate plots that are less market oriented, men say that it is rare to see women using pumps; "rather, they can grow simple vegetables for subsistence" (Kondoa, Tanzania).

The water requirements of men's and women's crops were also given as an explanation for why women should use manual lifting and application technologies. Pumps are considered more suitable for crops that men manage (tomatoes and onions), which can be flooded, whereas respondents said that the leafy greens managed by women require regular water application in smaller quantities, making them more suitable for watering cans, buckets, or drip irrigation.

In some communities, women help their husbands irrigate with pumps, as men note, "You can't do it alone" (Nyampande, Tanzania). In Ethiopia, women carry pumps to plots for their husbands to operate. However, men do not want women's agricultural labor to compromise domestic responsibilities, lest they "delay receiving ugali" (Mapea, Tanzania). However, they expect women to manage all domestic work while contributing equally in agricultural labor:

[Agricultural] responsibilities are for both of us, husband and wife... So even if it is to work in the irrigation field, my wife can still assist; if it is uprooting the trees, my wife can still help to collect them. The only activities which we differ are household chores, whereby when we reach home, she is the one cooking as I am resting. But in agricultural activities, the ratio is 50-50 (man in Rudewa Mbuyuni, Tanzania).

Women express concern about the time burden of irrigation and agriculture for their own well-being, their children's development, and their marriage, and note that the burden does not end when they rest for the day: "[The marriage] has to break because the whole day you were in the farm working, and it's very far. In the evening you have to do home chores, including attending to younger kids."

Asked how the community perceives women who irrigate, women say that those who use manual technologies are seen as "suffering" (Mkindo, Tanzania). Compounding the time burden is the fact that many of the irrigated fields are far from the home, requiring them to travel long distances and sometimes even sleep over at the field to guard against theft or prepare to receive water from the canal. Women also expressed frustration with drip irrigation in some of the HKI sites, since filling the tank that is connected to the drip line with water still requires heavy manual labor with buckets.

\footnotetext{
${ }^{3}$ As with gardens versus horticulture, the concept of "high-value" crops tends to refer to market value and does not consider the food security or nutritional value of home consumption.
}

Despite these norms around use rights of pumps, women in Ghana and Tanzania expressed their desire to obtain motorized pumps. In Mapea, Tanzania, a woman proposed that they should get "machines for pulling water ... rather than the punishment we get through irrigating by buckets; it delays the easiness of life. But if you get the machine, even a woman can do the work and get back home; hence it is good for the community."

In Dimbisinia, Ghana, the introduction of motor pumps saved women time in fetching water, which led to further changes in gender roles in agriculture: Men prepare the beds for both women's and men's plots, women nurse seedlings, and women do the marketing. Men in the Upper East Region sites in Ghana also expressed an incentive to support women to adopt irrigation technologies-preventing their wives from out-migrating during the dry season, which they say leaves men with all household domestic work.

\section{Management rights}

In a context where household members manage both joint and individual plots, there are potentially competing applications for one shared household irrigation technology. Therefore, the management right-where, when, and how the technology is used-has implications for crop choice, yields, and income generated by the different plot managers.

Throughout the discussions, men were described as the "pioneer," "supervisor," "manager," or "leader," while women are considered the "helper" for agricultural production activities, to "lead her army after my orders." Men typically control management rights, applying mechanized technologies to plots they control. Women's plots are not prioritized for irrigation. In Rudewa Mbuyuni, Tanzania, men explained that "wives must get permission from [their] husband to irrigate. [The husband] may refuse." Only in a few instances in Ghana, men operated household pumps on both men's and women's plots-with women noting that these wives were "lucky," suggesting that this is not common practice.

In these three countries, women are largely dependent on men for access to land. Men may allocate land to women that is not suitable for irrigation or close to a water source. Women's tenuous land rights also constrain decision-making power on the use of the land, since men can "just inform you that I have lent a land to so and so, therefore this time you will deal with the certain piece only" (Nyampande, Tanzania). In Ghana, however, women access land in the dry season through plots that are not being used as men engage in other economic activities, like fishing. In Nyangua, Ghana, women explained that because dry season irrigation is done on borrowed or rented plots, as opposed to inherited land, women have more control over cultivation decisions, including irrigation. 
Characteristics of the technology also influence management rights. Technologies that can be moved, like motorized pumps or hoses, can be more easily shared on different plots than a rope and washer or drip irrigation system. In Dimbisinia, Ghana, because men are responsible for digging wells during each dry season, men explain that they control the use of the water from those wells, including water-lifting pumps. In Lemo, Ethiopia, solar pumps and rope and washer waterlifting technologies are installed near the homestead, which enables women to use the water for both domestic purposes and irrigation. This gives women marginally more control over rainy and dry season management of those technologies than mobile technologies, such as motor pumps (Nigussie et al. 2017).

\section{Fructus rights}

Fructus rights are less commonly measured as a project outcome compared with the previous two rights, perhaps because of persistent assumptions that households pool resources or that what happens within households is beyond projects' control or ability to monitor. However, our findings show that projects can change how they affect fructus rights. ${ }^{4}$ Household members may have stronger or weaker fructus rights according to who decides whether, when, and where to sell produce and who directly handles revenues from sale. These different decisions particularly affect knowledge of revenues and subsequent bargaining power over use of earnings.

In Tanzania, women in nearly every community mentioned that it is common for men and women to collaborate throughout the season on irrigated agricultural production, but when the time comes to sell, men sell away from the farm gate, without women's knowledge or consultation about the quantity, timing, or price of sale. Men therefore have greater fructus rights over this income: "What you harvest is his... That is the truth" (Nyamazugo, Tanzania). A woman in Mawemairo explains:

In most cases, men involve us in decision making, but during harvesting, you are left behind. I don't know how others see it ... During cultivation, there is love at home, good talks like, "This year after we harvest, we will make this and that, and we will take our child to there and do this for him." You use all your energy, and when harvesting time comes, after taking the sacks in the warehouse, and you touch him, then conflict will

\footnotetext{
4 The outputs of a technology include irrigated crops (e.g., tomatoes, onions, vegetables), byproducts (e.g., crop residues for fodder, wild herbs), and income generated by the technology (e.g., revenue from selling crops, renting out a pump, charging mobile phone batteries using the photovoltaic panels on a solar pump)
}

rise in the house, and he will tell you, "With the little income we have, do you think we can manage big things as those?" Then you keep quiet.

Many women reported noncooperative relationship around agricultural sales: "when it comes to selling, it's a husband who does it, and thereafter he will just inform you about the sales and put all the money in his pocket" (Nyampande, Tanzania). Men mention separately that they do not need to share this information: "A man can sell and say nothing."

Women in three communities in Tanzania (Mapea, Mawemairo, and Nyampande, in Babati and Sengerema districts) discuss how irrigated rice paddy is now sold at warehouses, almost exclusively by men. One woman said her husband "signs the sacks at the warehouse and sells, but you won't even know of the amounts, whether he gives you a fake calculation. You just have to accept." She explains:

But as days goes by, you can't go daily to check them [the sacks], since you aren't the one who signed for it inside there, because his fellow men will think of me oppositely, so I just remain at home. If you will need rice and tell him, then he will look how many kilograms can cater for this family, but he doesn't bring. When you remind him again, he will tell you, "stop disturbing" while he goes to the machinery store and grinds paddy but doesn't tell you. After some days if you tell him, "I would like to get a new kitenge," he will ask you, "Where is the money?" While he has already sold it and it's over. The next season comes, and you all go to the farm again (Mapea, Tanzania).

A woman in Mawemairo describes how her husband stores the full paddy harvest at the warehouse and "sells without notifying you... and if you ask, it's a conflict inside the house." The Mawemairo women also explain that income from irrigated paddy does help them "build good houses," but they point out that they do not have a say over how this income is spent: "He only cares you are living in a good house, you have a TV and good utensils. Then he expects you to be satisfied" (Mawemairo, Tanzania). In Mapea community, a woman explained, "If you tell him [what to do with the income], he asks you, 'Did you come with it from your home?",

Women sometimes hold fructus rights below a revenue threshold. In several communities where HKI promoted home gardens with drip irrigation, women explained that they retain control over income if revenues are low: "Men

\footnotetext{
5 Meaning, did the woman bring it from her natal home; women may have stronger claims on assets brought to marriage. See Quisumbing and Maluccio (2003) for further analysis of the empowerment effects of assets brought to marriage.
} 
regard vegetable gardening as a low income generating activity compared to tomatoes even if the processes are the same" (Nyamazugo, Tanzania). In Nyamatongo, a woman explains that the sale of vegetables is "your money and he doesn't ask you." Because men's "eyes are onto high-income activities that generate money in a lump sum, that is why they are not so much into vegetables, though they can still borrow money from you" (Nyampande, Tanzania). However, in Nyampande, women note that men now "can even ask for 1000 shillings, and you can't deny him because he knows you have money."

Women across sites value the independence and respect from generating income. Women appreciate not having to ask their husbands for money to purchase food or other household needs. In Robit, Ethiopia, women said, "We do not expect money from men's hand; there will be no problem for [women to pay for] home expenses" because "generating income avoids dependency on men." Women in Nyamatongo, Tanzania note: "It has changed due to gardens ... It's different because I don't depend on a man, since I sell the vegetables and get money and buy exercise books [for children's schooling], buy soaps and clothes."

In the Ghana sites, women play an active role in taking produce to markets and negotiating prices. Both women and men see irrigation as enabling women to obtain their own income and be less reliant on men. Women expressed satisfaction that after adopting irrigation practices, they were able to pay school fees and medical costs for their children without relying on their husbands, as well as purchase small items for themselves, such as new shoes. In Bihinayiili, Ghana, women said: "Our husbands cannot tell us how to spend our income." As noted above, in one site, men particularly supported women's irrigation on the women's plots to increase their wives' cash income because this meant the women were less likely to migrate to work as hired farm labor.

Women's fructus rights may also be limited to the types of purchases they can make. In Lemo, Ethiopia, women's fructus right extends only to using the income from irrigated farming on food and small household purchases, but in Robit, Ethiopia, women bought clothes with the income earned from irrigating vegetables near the household using manual water-lifting technologies.

Some cases noted nonfinancial benefits related to social status. Women in Zanlerigu, Ghana, said that irrigated farming (with watering cans) had increased their income, and as their individual income increased, so did their joint decision

\footnotetext{
6 This distinction between referring to women growing vegetables as "gardening" versus growing tomatoes (which are a vegetable but presumably a monocrop) mirrors the development discourse that often refers to the former as "kitchen gardens" and the latter as "horticulture."
}

making with their spouse. Women in Dimbisinia in Ghana, said that irrigated farming "makes people appreciate you ... gives you a sense of belonging."

\section{Alienation rights}

Alienation rights refer to the right to transfer by sale, lease, gift, or inheritance. We did not find instances of alienation of irrigation technology itself, as there is not much of a secondary market for the equipment. However, patterns of alienation rights over other assets indicate that they are held predominantly by men. In Nyamazugo, Tanzania, men say that it is common to give woman a plot of land and take it away from her at the husband's discretion, and she cannot protest as long as men fulfill their role by bringing home meat for the family. Women in Nyampande similarly reflect that husbands can lease out a piece of land, which women may have been using, and only inform them afterward. Women in this community also comment that they do not have alienation rights over even small assets like poultry: "You know they are talking of gender equality, but in reality, it does not exist. At times, you may have to ask for permission to slaughter chicken for visitors; otherwise, if you force doing it, you will have to pay for it later."

In Ghana, pumps are major assets, as valuable as cows, and therefore are considered men's property within the household. In Nyangua, women said that cattle belong to the husband regardless of whose money was used to buy them. Likewise, in Zanlerigu, women discussed pumps as assets similar to cattle; women can "own" animals, but they are regarded as men's assets and a woman needs her husband's permission to buy or sell animals. Women say that even if they are given a pump by a project or purchase one on their own, the men in the household will own the pump.

\section{Discussion and conclusion}

Despite the associated time and energy burden, women value irrigation, particularly for crops and plots where they control management and fructus rights. However, in our study sites, women typically hold management and fructus rights on small-scale horticulture plots where they use labor-intensive irrigation methods. On these plots, they secure these rights in exchange for providing nearly all the labor to irrigate, with little help from husbands or hired labor. The time they can dedicate to this work is limited, after prioritizing their labor for domestic responsibilities and agricultural work on family plots. Men then point to women's domestic work obligations and resulting time constraints to argue that women's greater investment of time on their own plots or wider rights to a technology on the family plot will harm women's ability to carry out their familial duties. 
Even though use and management rights are not a guarantee of fructus or alienation rights, use rights do seem to strengthen claims to fructus and alienation rights. Women expressed feeling cheated when their husbands sell paddy that was produced through their labor without the women's knowledge. Despite this awareness of inequity, none of the women cited examples of successfully negotiating for fructus rights. Information asymmetry regarding the sale of irrigated produce, time constraints, limited mobility, and the fear of compromising their economic security derived through these relationships strongly inhibit women's ability to negotiate their fructus rights.

In their review of gender differences in agricultural technologies, Peterman et al. (2010) note that given equal access to technology, men and women are often equally likely to adopt technologies. Yet access is rarely equal. Much of the gender and technology adoption research to date has thus focused on understanding gendered constraints around access to technology (Peterman et al. 2010), including factors that disadvantage women from learning about, purchasing, and using a technology (Magnan et al. 2014; Ragasa et al. 2014), and aspects of technological design and choice that better address women's needs and preferences (Carr and Hartl 2010; Quisumbing and Pandolfelli 2010). Although it is important to consider these factors, the emphasis on gendered constraints to access effectively treats technology acquisition as the end goal. Without attention to household structure and intrahousehold dynamics, it is only an assumption that the woman who appears to adopt the technology actually controls and benefits from it.

Applying an adapted bundle of rights framework to the household allows us to draw new attention to the intrahousehold implications of smallholder technology adoption. Household members hold overlapping, dynamic, and negotiable rights over technology. How rights are distributed varies from household to household. Identifying the use, fructus, management, and alienation rights held by different people reveals intrahousehold differences in control over technology, experience of its costs and benefits, and associated shifts in power. Furthermore, expectations about whether women can claim their rights likely influence men and women's willingness to try out a technology in the first place. Fisher et al. (2000) found that where wives had higher bargaining power, households were more likely to reject adopting labor-intensive cattle stabling technology, which women perceived would cause an increase in their labor and loss of control over milk sales. Other studies have found that women reduce their labor on their husband's plots to minimum acceptable levels when they do not expect to be able to control the outputs (van Koppen and Hussain 2007).

Although a focus on removing barriers to women's acquisition of technologies is well intended, projects that promote irrigation technology for women should be aware that rights to technology can be subject to a form of elite capture within the institution of the household. As previous studies have found, in the absence of complementary institutional or social change, targeting women with technology alone is unlikely to confer full rights over the technology to women, since the rules of the household often override any norms or expectations promoted by projects, and historically men have been adept at interceding to appropriate a technology or economic activity once it is shown to be profitable (Jones 1983; von Braun and Webb 1989; Quisumbing and Kumar 2011).

Of the set of rights in this framework, use rights are most commonly measured by projects and fructus rights are most often overlooked. So-called "female-friendly technologies" aim to design products for women's ease and comfort in use. However, the right to use a technology does not necessarily confer other rights. In the absence of other rights, the use right may simply represent greater labor burden for women.

Fructus rights, in contrast, need to be systematically addressed. Fructus rights are an important gendered impact of technology adoption and a factor influencing adoption and investment behavior. Though women face significant constraints to claiming fructus rights within the household, they highly value these rights and employ different strategies to maintain them. If they perceive that men are likely to appropriate fructus rights beyond a certain threshold of income, some women choose economic activities that generate lower sums of income and are sold continually over time, rather than "lumpy" (large and infrequent) sales. Projects that attempt to shift women's production to different crops, or to commercialize traditional women's crops, may also risk women losing fructus rights (see Fischer and Qaim [2012] for the case of commercialized banana production in Kenya). In addition, fructus rights are particularly weak when there is information asymmetry over the sales of joint production. Formalized value chains associated with irrigated production may increase information asymmetry. Support for women's claims to fructus rights could include increased access to market information, joint digital financial services that provide transaction alerts, and transparent and accessible documentation of sales.

Notably, the cases suggest that household rights to technology are potentially malleable. Transformative approaches can work inside and outside the household. Such approaches can engage with couples and communities to reflect on gender roles and relations, and support groups of women to reflect on their shared challenges and rights while receiving technologies, assets, and training to secure their benefits from production. On the latter approach, we found that projects targeting women struggled when men blocked women's participation in groups or chose not to tell them about meetings and other opportunities. Informing men about the purpose of these activities and demonstrating the benefits to 
the family may facilitate men's support for women's involvement, and men's respect for women can grow when women demonstrate that they can bring in income through these activities (Naved 2000; Quisumbing and Pandolfelli 2010). Group distribution of technology can have other benefits beyond securing rights. Quisumbing and Kumar (2011) find that agricultural technologies disseminated through women's groups not only lead to an increase in women's assets relative to men's within the household, but also strengthened women's social capital, which substituted in the short term for lack of physical capital and in the long term helped build women's assets.

Rights to irrigation technology are linked to gendered land rights and division of labor. Just as men often allocate plots of land to women only for subsistence-level production (Lambrecht 2016), our research showed that women rarely used mechanized irrigation technologies on their own plots of land. On plots that they managed, women predominantly used manual irrigation technologies without help from their husbands or hired labor. Mechanized irrigation technologies were largely applied on men's plots, where men controlled most rights, and women held only use rights to these technologies as "helpers" to their husbands.

Nonetheless, women do express demand for mechanized irrigation technologies, seeking greater financial independence and household food security. Initial evidence from these cases suggests the aspects of technologies that women prefer in the context of intrahousehold rights. In Ethiopia, women saw motor pumps as adding to their time burden and instead preferred solar pumps that could reduce both domestic and field labor requirements. Solar appears to be a promising technology for women (Burney et al. 2013; IRENA 2016). Nigussie et al. (2017) identified that women preferred solar pumps located near the household where women had more control over information and production. Solar pumps with lower power capacity may limit the potential groundwater lifting rate but could be suitable for crops that women produce on small plots near the household and over which women have greater control over revenues. Multiuse pumps, sited in locations convenient for both men's and women's plots and compatible with different uses of water and application methods, could promote joint use and shared management rights over water-lifting technology. Portability and location of installation may therefore affect women's fructus rights.

Further research is needed to test and apply this framework to inform inclusive technology diffusion efforts, including how design characteristics of technology and adoption modality affect the intrahousehold distribution of rights, which rights men and women prefer in different contexts, and how different empowerment approaches and aspects of empowerment (e.g. literacy, socioeconomic status) can facilitate women's rights to technology within the household. This study focused on women in married (male-headed) households in Ethiopia, Ghana, and Tanzania, where women often depend on husbands for access to land and typically cultivate both a joint and individually managed plot with some independent control over income. The framework may not apply as well to other settings, for example where male- rather than dual-farming systems are dominant (van Koppen and Hussain 2007) or in other geographies (see Akter et al. [2017] for how these challenges, largely studied and understood in the African context, differ in Southeast Asia). As such, it is meant to suggest new lines of inquiry rather than prescribe a universally applicable intervention approach.

Irrigation technologies can generate new livelihood opportunities, enhance resilience, and increase productivity. Development partners promoting these technologies could strengthen development outcomes by understanding how technologies are used, by whom, and for what purpose. Some interventions assume that simply reaching women with technology-for example, distributing motor pumps to women-leads to empowerment, and so less attention is given to monitoring if or how this happens (Johnson et al. 2017). Instead, investigating how rights are distributed can shed light on how technology adoption affects women and men differently within a household. This evidence will help ensure that technology adoption strategically advances development objectives such as food and nutritional security, resilience, and women's empowerment, rather than taking technology adoption as an end in and of itself.

Acknowledgements We gratefully acknowledge Likie Nigussie (Ethiopia), Christopher Magomba and Elizabeth Mshote (Tanzania), and Elsie Odonkor and Afishata Mohammed Abujaja (Ghana) for leading data collection and skillfully facilitating discussions with men and women in the three countries. We recognize the invaluable time and willingness to share personal experiences that discussion participants generously extended to the research team in each country. We thank Claudia Ringler and David Spielman for providing helpful feedback at multiple stages of paper preparation. This work was undertaken as part of the Feed the Future Innovation Lab for Small-Scale Irrigation supported by the United States Agency for International Development (USAID) and forms part of the CGIAR Research Programs on Water, Land, and Ecosystems (WLE) and Policies, Institutions, and Markets (PIM).

Funding This study was funded by the Feed the Future Innovation Lab for Small-Scale Irrigation through the United States Agency for International Development (USAID) (Grant Number AID-OAA-A-13-00055).

\section{Compliance with ethical standards}

Conflict of interest The authors declare that they have no conflict of interest.

Ethical approval All procedures performed in studies involving human participants were in accordance with the ethical standards of the insti- 
tutional and/or national research committee and with the 1964 Helsinki Declaration and its later amendments or comparable ethical standards.

Open Access This article is distributed under the terms of the Creative Commons Attribution 4.0 International License (http://creativeco mmons.org/licenses/by/4.0/), which permits unrestricted use, distribution, and reproduction in any medium, provided you give appropriate credit to the original author(s) and the source, provide a link to the Creative Commons license, and indicate if changes were made.

\section{References}

Akter, S. P., J. Rutsaert, N. Luis, S. Htwe, B. San, Raharjo, and A. Pustika. 2017. Women's empowerment and gender equity in agriculture: A different perspective from Southeast Asia. Food Policy 69 (C): 270-279. https://doi.org/10.1016/j.foodpol.2017.05.003.

Alchian, A., and H. Demsetz. 1972. Production, information costs, and economic organization. American Economic Review 62 (S): 777-795.

Alderman, H., P. Chiappori, L. Haddad, J. Hoddinott, and R. Kanbur. 1995. Unitary versus collective models of the household: Is it time to shift the burden of proof? World Bank Research Observer 10 (1): 1-19. https://doi.org/10.1093/wbro/10.1.1.

Ani, A., O. Ogunnika, and S. S. Ifah. 2004. Relationship between socio-economic characteristics of rural women farmers and their adoption of farm technologies in Southern Eboni State, Nigeria. International Journal of Agriculture and Biology 6 (5): 802-805.

Beekman, W., G. J. Veldwisch, and A. Bolding. 2014. Identifying the potential for irrigation development in Mozambique: Capitalizing on the drivers behind farmer-led irrigation expansion. Physics and Chemistry of the Earth, Parts A/B/C 76-78:54-63.

Benjaminsen, T. A., and B. Ba. 2009. Farmer-herder conflicts, pastoral marginalization and corruption: A case study from the Inland Niger Delta of Mali. The Geographical Journal 175 (1): 71-81. https://doi.org/10.1111/j.1475-4959.2008.00312.x.

Burney, J. A., R. Naylor, and S. Postel. 2013. The case for distributed irrigation as a development priority in Sub-Saharan Africa. Proceedings of the National Academy of Sciences 110 (31): 1251312517. https://doi.org/10.1073/pnas.1203597110.

Carr, M., and M. Hartl. 2010. Lightening the load: Labour-saving technologies and practices for rural women. Rugby: International Fund for Agricultural Development and Practical Action.

Conley, T., and C. Udry. 2001. Social learning through networks: The adoption of new agricultural technologies in Ghana. American Journal of Agricultural Economics 83 (3): 668-673. https://doi. org/10.1016/j.agwat.2013.07.005.

de Fraiture, C., and M. Giordano. 2014. Small private irrigation: A thriving but overlooked sector. Agricultural Water Management 131: 167-174. https://doi.org/10.1016/j.agwat.2013.07.005.

Domènech, L. 2015. Improving irrigation access to combat food insecurity and undernutrition: A review. Global Food Security 6: 24-33. https://doi.org/10.1016/j.gfs.2015.09.001.

Doss, C. R. 1996. Testing among models of intrahousehold resource allocation. World Development 24 (10): 1597-1609. https://doi. org/10.1016/0305-750X(96)00063-0.

Doss, C. R. 2001. Designing agricultural technology for African women farmers: Lessons from 25 years of experience. World Development 29 (12): 2075-2092. https://doi.org/10.1016/S0305 $-750 \mathrm{X}(01) 00088-2$.

Doss, C. R., and R. Meinzen-Dick. 2015. Collective action within the household: Insights from natural resource management. World
Development 74: 171-183. https://doi.org/10.1016/j.world dev.2015.05.001.

Doss, C. R., and M. Morris. 2001. How does gender affect the adoption of agricultural innovations? The case of improved maize technology in Ghana. Agricultural Economics 25 (1): 27-39. https://doi. org/10.1111/j.1574-0862.2001.tb00233.x.

Doss, C. R., W. M. Mwangi, H. Verkuijl, and H. De Groote. 2003. Adoption of maize and wheat technologies in eastern Africa: A synthesis of the findings of 22 case studies. International Maize and Wheat Improvement Center (CIMMYT) Economics Working Paper. Mexico City: CIMMYT. http://repository.cimmy t.org/handle/10883/1037. Accessed 15 March 2017.

Doss, C. R., C. D. Deere, A. D. Oduro, and H. Swaminathan. 2014 The gender asset and wealth gaps. Development 57 (3-4): 400 409. https://doi.org/10.1057/dev.2015.10.

Drechsel, P., A. Olaleye, A. Adeoti, L. Thiombiano, B. Barry, and K. Vohland. 2006. Adoption drivers and constraints of resource conservation technologies in Sub-Saharan Africa. http://hdl. handle.net/10568/36743 (unpublished paper). Accessed 15 March 2017.

Eggertsson, T. 1990. Economic behavior and institutions. Cambridge: Cambridge University Press.

Ethiopian Agricultural Transformation Agency. 2018. Irrigation and drainage: Why is transformation needed in this program area? http://www.ata.gov.et/programs/sustainable-inclusive-growth/ irrigation-drainage. Accessed 3 Feb 2018.

Fischer, E., and M. Qaim. 2012. Gender, agricultural commercialization, and collective action in Kenya. Food Policy 4 (3): 441-453.

Fisher, M., R. Warner, and W. Masters. 2000. Gender and agricultural change: Crop-livestock integration in Senegal. Society and Natural Resources 13 (3): 203-222. https://doi.org/10.1080/08941 9200279063.

Helen Keller International. 2014. Helping families grow better food: The enhanced homestead food production program. http://www. hki.org/our-work/improving-nutrition/helping-families-grow-bette r-food\#.WPEjIYWcGwA. Accessed 12 May 2017.

Hunecke, C., A. Engler, R. Jara-Rojas, and P. M. Poortvliet. 2017. Understanding the role of social capital in adoption decisions: An application to irrigation technology. Agricultural Systems 153: 221-231. https://doi.org/10.1016/j.agsy.2017.02.002.

Huyer, S. 2016. Closing the gender gap in agriculture. Gender, Technology and Development 20 (2): 1-12. https://doi.org/10.1177/09718 52416643872.

IRENA. 2016. Solar pumping for irrigation: Improving livelihoods and sustainability. IRENA Policy Brief. Abu Dhabi: The International Renewable Energy Agency.

Johnson, N. L., C. Kovarik, R. Meinzen-Dick, J. Njuki, and A. Quisumbing. 2016. Gender, assets, and agricultural development: Lessons from eight projects. World Development 83: 295-311. https://doi.org/10.1016/j.worlddev.2016.01.009.

Johnson, N., M. Balagamwala, C. Pinkstaff, S. Theis, R. MeinzenDick, and A. Quisumbing. 2017. How do agricultural development projects aim to empower women? Insights from an analysis of project strategies. IFPRI Discussion Paper 1609. Washington, DC: International Food Policy Research Institute.

Jones, C. 1983. The mobilization of women's labor in cash crop production: A game theoretic approach. American Journal of Agricultural Economics 65 (5): 1049-1054. https://doi. org/10.2307/1240417.

Lambrecht, I. B. 2016. "As a husband I will love, lead, and provide." Gendered access to land in Ghana. World Development 88: 188200. https://doi.org/10.1016/j.worlddev.2016.07.018.

Lambrecht, I., B. Vanlauwe, R. Merckx, and M. Maertens. 2014. Understanding the process of agricultural technology adoption: 
Mineral fertilizer in eastern DR Congo. World Development 59: 132-146. https://doi.org/10.1016/j.worlddev.2014.01.024.

Lindner, R. K., P. G. Pardey, and F. G. Jarrett. 1982. Distance to information source and the time lag to early adoption of trace element fertilizers. Australian Journal of Agricultural Economics 26 (2): 98-113. https://doi.org/10.1111/j.1467-8489.1982.tb00618.x.

Magnan, N., K. Gulati, T. Lybbert, and D. Spielman. 2014. Gender dimensions of social networks and technology adoption in eastern Uttar Pradesh, India. http://cega.berkeley.edu/assets/cega_event s/61/3B_Role_of_Gender_in_Networks__Bargaining__and Employment.pdf.

Meinzen-Dick, R., and M. Zwarteveen. 1998. Gendered participation in water management: Issues and illustrations from water users' associations in South Asia. Agriculture and Human Values 15 (4): 337-345. https://doi.org/10.1023/A:1007533018254.

Meinzen-Dick, R., A. Quisumbing, J. Behrman, P. Biermayr-Jenzano, V. Wilde, M. Noordeloos, C. Ragasa, and N. Beintema. 2011. Engendering agricultural research. IFPRI Monograph. Washington, DC: International Food Policy Research Institute.

Merrey, D. 2006. Agricultural water management technologies for small-scale farmers in southern Africa: An inventory and assessment of experiences, good practices and costs. Pretoria: International Water Management Institute.

Namara, R. E., L. Hope., E. O. Sarpong, C. de Fraiture, and D. Owusu. 2014. Adoption patterns and constraints pertaining to small-scale water lifting technologies in Ghana. Agricultural Water Management 131: 194-203. https://doi.org/10.1016/j.agwat.2013.08.023.

Naved, R. T. 2000. Intrahousehold impact of the transfer of modern agricultural technology: A gender perspective. Food Consumption and Nutrition Division Discussion Paper 85. Washington, DC: International Food Policy Research Institute.

NEPAD (New Partnership for Africa Development)/CAADP (Comprehensive Africa Agricultural Development Program). 2009. Sustainable land and water management: The CAADP Pillar I program. Midrand: NEPAD.

Nigussie, L., N. Lefore, P. Schmitter, and A. Nicol. 2017. Gender and water technologies: Water lifting for irrigation and multiple purposes in Ethiopia. Africa RISING Report. Addis Ababa: International Livestock Research Institute. https://cgspace.cgiar.org/ bitstream/handle/10568/79989/AR_Ethiopia_gender_water_feb20 17.pdf?sequence $=1$. Accessed 2 March 2017.

Njuki, J., E. Waithanji, B. Sakwa, J. Kariuki, E. Mukewa, and J. Ngige. 2014. A qualitative assessment of gender and irrigation technology in Kenya and Tanzania. Gender, Technology, and Development 18(3): 303-340. http://gtd.sagepub.com/content/18/3/303. short. Accessed 25 Aug 2016.

Olwande, J., G. Sikei, and M. Mathenge. 2009. Agricultural technology adoption: A panel analysis of smallholder farmers' fertilizer use in Kenya. CEGA Working Paper Series AfD-0908. Berkeley: University of California Center of Evaluation for Global Action. https ://escholarship.org/uc/item/9666220j. Accessed 15 March 2017.

Peterman, A., J. Behrman, and A. Quisumbing. 2010. A review of empirical evidence on gender differences in non-land agricultural inputs, technology, and services in developing countries. ESA Working Paper No. 11-11. Rome: Food and Agriculture Organization of the United Nations. http://www.fao.org/3/a-am316e.pdf. Accessed 29 Aug 2016.

Peterman, A., A. Quisumbing, J. Behrman, and E. Nkonya. 2011. Understanding the complexities surrounding gender differences in agricultural productivity in Nigeria and Uganda. The Journal of Development Studies 47 (10): 1482-1509. https://doi. org/10.1080/00220388.2010.536222.

Quisumbing, A. R. 1995. Gender differences in agricultural productivity: A survey of empirical evidence. Food Consumption and Nutrition Division Discussion Paper 5. Washington, DC: International Food Policy Research Institute.
Quisumbing, A. R., and N. Kumar. 2011. Does social capital build women's assets? The long-term impacts of group-based and individual dissemination of agricultural technology in Bangladesh. Journal of Development Effectiveness 3 (2): 220-242. https://doi. org/10.1080/19439342.2011.570450.

Quisumbing, A. R., and J. Maluccio. 2003. Resources at marriage and intrahousehold allocation: Evidence from Bangladesh, Ethiopia, Indonesia, and South Africa. Oxford Bulletin of Economics and Statistics 65 (3): 283-328. https://doi.org/10.1111/1468-0084. t01-1-00052.

Quisumbing, A. R., and L. Pandolfelli. 2010. Promising approaches to address the needs of poor female farmers: Resources, constraints, and interventions. World Development 38 (4): 581-592. https:// doi.org/10.1016/j.worlddev.2009.10.006.

Quisumbing, A. R., S. Roy, J. Njuki, K. Tanvin, and E. Waithanji. 2013. Can dairy value-chain projects change gender norms in rural Bangladesh? Impacts on assets, gender norms, and time use. IFPRI Discussion Paper 01311. Washington, DC: International Food Policy Research Institute.

Ragasa, C., D. Sengupta, M. Osorio, N. Ourabah Haddad, and K. Mathieson. 2014. Gender-specific approaches, rural institutions and technical innovations. Rome: Food and Agricultural Organization of the United Nations, International Food Policy Research Institute, and Global Forum on Agricultural Research. http://ebrary.ifpri.org/cdm/ref/collection/p15738coll2/id/12903 9. Accessed 25 Aug 2016.

Roy, S., J. Ara, N. Das, and A. Quisumbing. 2015. "Flypaper effects" in transfers targeted to women: Evidence from BRAC's "Targeting the Ultra Poor" program in Bangladesh. Journal of Development Economics 117: 1-19. https://doi.org/10.1016/j.jdeve co.2015.06.004.

Schlager, E., and E. Ostrom. 1992. Property-rights regimes and natural resources: A conceptual analysis. Land Economics 68 (3): 249-262.

Siebert, S., J. Burke, J. M. Faures, K. Frenken, J. Hoogeveen, P. Doll, and F. T. Portmann. 2010. Groundwater use for irrigation-A global inventory. Hydrology and Earth Systems Sciences 14: 1863-1880. https://doi.org/10.5194/hess-14-1863-2010.

Tiwari, N. 2010. Economic and technological constraints facing farm women. International Journal of Rural Studies 17 (1): 1-5.

Upadhyay, B. 2004. Gender aspects of smallholder irrigation technology: Insights from Nepal. Journal of Applied Irrigation Science 39(2): 315-327. http://lib.icimod.org/record/11464/files/4960. pdf. Accessed 29 Aug 2016.

van Koppen, B. 1998. Water rights, gender, and poverty alleviation: Inclusion and exclusion of women and men smallholders in public irrigation infrastructure development. Agriculture and Human Values 15 (4): 361-374. https://doi. org/10.1023/A:1007537119163.

van Koppen, B., and I. Hussain. 2007. Gender and irrigation: Overview of issues and options. Irrigation and Drainage 56: 289298. https://doi.org/10.1002/ird.296.

van Koppen, B., L. Hope, and W. Colenbrander. 2012. Gender aspects of small-scale private irrigation in Africa. IWMI Working Paper 153. Colombo: International Water Management Institute.

von Braun, J., and P. Webb. 1989. The impact of new crop technology on the agricultural division of labor in a West African setting. Economic Development and Cultural Change 37 (20): 513-534.

von Benda-Beckmann, F., K. von Benda-Beckmann, and M. Wiber. 2006. The properties of property. In Changing properties of property, eds. F. von Benda-Beckmann, K. von Benda-Beckmann, and M. Wiber, 1-39. New York: Berghahn Books.

Woodhouse, P., G. J. Veldwisch, J. Venot, D. Brockington, H. Komakech, and A. Manjichi. 2017. African farmer-led irrigation 
development: Re-framing agricultural policy and investment? The Journal of Peasant Studies 44 (1): 213-233. https://doi. org/10.1080/03066150.2016.1219719.

Xie, H., L. You, B. Wielgosz, and C. Ringler. 2014. Estimating the potential for expanding smallholder irrigation in Sub-Saharan Africa. Agricultural Water Management 131 (1): 183-193. https ://doi.org/10.1016/j.agwat.2013.08.011.

You, L., C. Ringler, G. Nelson, U. Wood-Sichra, R. Robertson, S. Wood, Z. Guo, T. Zhu, and Y. Sun. 2010. What is the irrigation potential for Africa? A combined biophysical and socioeconomic approach. Environment and Production Technology Division. IFPRI Discussion Paper 993. Washington, DC: International Food Policy Research Institute.

Zwarteveen, M. Z. 1997. Water: From basic need to commodity: A discussion on gender and water rights in the context of irrigation. World Development 25 (8): 1335-1349. https://doi.org/10.1016/ S0305-750X(97)00032-6.
Sophie Theis is a Research Analyst in the Environment and Production Technology Division of the International Food Policy Research Institute, Washington, DC.

Nicole Lefore is a Senior Project Manager, Research for Development, at the International Water Management Institute, Pretoria, South Africa.

Ruth Meinzen-Dick is a Senior Research Fellow in the Environment and Production Technology Division of the International Food Policy Research Institute, Washington, DC.

Elizabeth Bryan is a Senior Research Analyst in the Environment and Production Technology Division of the International Food Policy Research Institute, Washington, DC. 